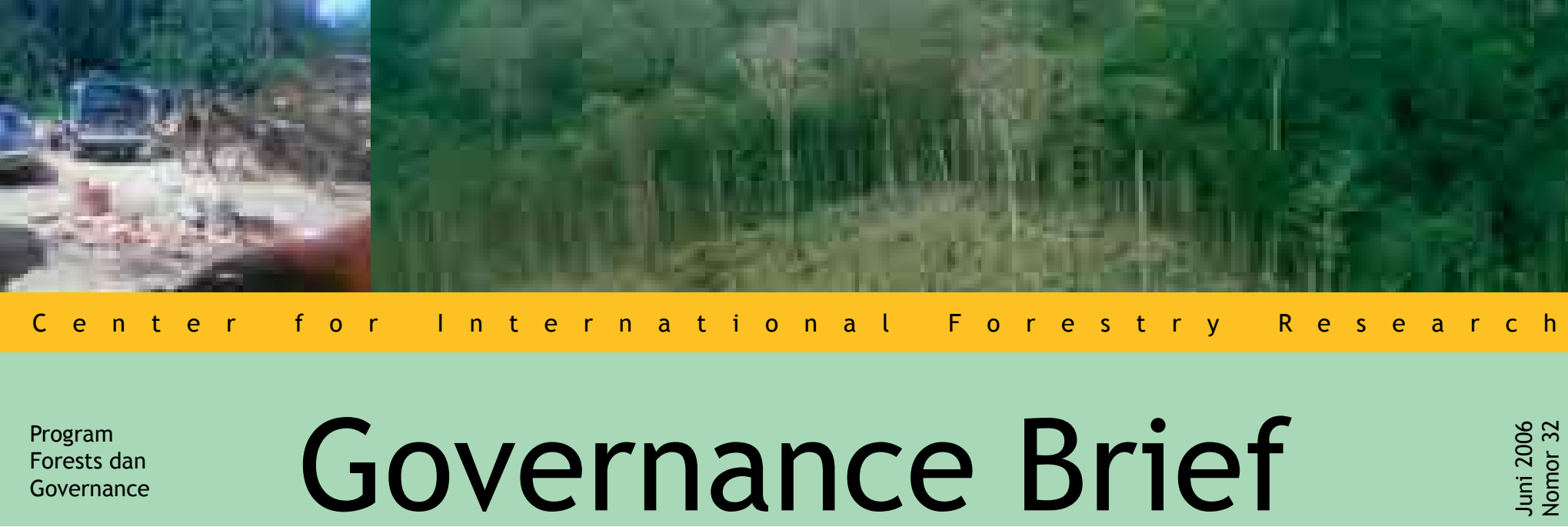

\title{
Melegalkan partisipasi masyarakat dalam kebijakan
}

\author{
Sudirman \\ Dosen FH Universitas Jambi - Peneliti PSHK-ODA
}

\begin{abstract}
Selama ini, pihak eksekutif dan DPRD melahirkan berbagai kebijakan yang kurang atau bahkan sama sekali belum melibatkan masyarakat pada aspek yang bersangkut paut dengan kepentingan mereka. Padahal dengan semangat desentralisasi, sudah muncul paradigma baru dalam proses pengambilan kebijakan yang memungkinkan pelibatan masyarakat' lebih luas dalam pembangunan daerah.
\end{abstract}

Salah satu masalah adalah belum memadainya produk perundangan daerah yang dapat mendukung terlaksananya partisipasi masyarakat dalam setiap proses lahirnya kebijakan. Untuk memecahkan masalah ini perlu dilakukan pembaruan mekanisme pembuatan kebijakan daerah. Pendekatan strategis yang dapat dilakukan adalah membentuk peraturan daerah yang mengatur mekanisme pembuatan kebijakan daerah partisipatif.

Pembaruan itu meliputi upaya untuk mensistematisasi secara terpadu mekanisme pembuatan kebijakan daerah dalam satu ketentuan sehingga semua proses pembuatan kebijakan daerah mengacu pada satu sumber. Diharapkan DPRD maupun eksekutif mengikuti ketentuan tersebut dan terciptanya ruang bagi masyarakat terlibat dalam pembuatan kebijakan daerah.

Naskah ini merupakan kelanjutan dari laporan hasil penelitian tentang "Mekanisme Pengambilan Kebijakan Daerah di Bidang Kehutanan: Proses, Implementasi dan Dampak Desentralisasi pada Sektor Kehutanan di Tanjung Jabung Barat, Jambi" yang didanai oleh ACIAR dan DFID dalam proyek: Dapatkah Desentralisasi Memberikan Manfaat untuk Hutan dan Masyarakat Miskin? Hasil penelitian itu merekomendasikan bahwa masyarakat perlu terlibat dalam proses pembuatan kebijakan sebagai konsekuensi belum implementatifnya produk kebijakan yang dihasilkan selama ini.

\section{Partisipasi masyarakat dalam pembuatan kebijakan}

Partisipasi masyarakat diartikan sebagai proses yang melibatkan masyarakat umum dalam pengambilan keputusan, perumusan, pelaksanaan, dan pengawasan kebijakan dalam penyelenggaraan pemerintahan, pembangunan, serta pembinaan masyarakat ${ }^{2}$.

Partisipasi masyarakat dalam pembuatan kebijakan berada pada urutan yang sangat tinggi dalam agenda desentralisasi, seperti yang diamanatkan oleh UU No. 18/1997 jo UU No. 34/2000, UU No. 41/1999, UU No. 10/2004, dan UU No. 32/2004³. Ini berarti bahwa undang-undang harus menjamin partisipasi masyarakat. Dengan partisipasi masyarakat diharapkan:

1. Kebijakan daerah didasarkan terutama pada kepentingan dan kebutuhan masyarakat. Berbagai kebijakan atau peraturan akan lebih sesuai dengan kenyataan dan lebih mungkin memenuhi harapan-harapan masyarakat lokal.

2. Mendorong masyarakat lokal untuk lebih mematuhi kebijakan atau peraturan dan bertanggung jawab secara sosial. Masyarakat akan cenderung lebih patuh terhadap peraturan yang pembuatannya melibatkan mereka secara aktif. 
3. Memberdayakan pemerintah daerah untuk mendemokratisasikan proses pembuatan kebijakan dan lebih bertanggung gugat kepada pemilih mereka. Konsultasi terbuka dengan para pemangku kepentingan, seperti universitas, LSM, dan masyarakat umum, memungkinkan "pengawasan dan keseimbangan” menjadi bagian dalam proses.

Provinsi Jambi telah mencoba membangun partisipasi masyarakat dalam proses pembuatan kebijakan melalui Program Pembangunan Daerah (Propeda) ${ }^{4}$. Hal ini merupakan langkah awal yang baik guna lebih mendorong partisipasi yang lebih luas masuk dalam mekanisme pembuatan kebijakan.

\section{Mekanisme partisipasi dalam pembuatan kebijakan daerah}

Dari rangkaian proses pembuatan kebijakan ${ }^{5}$ yang ada dan melihat berbagai kelemahan ${ }^{6}$ produk kebijakan yang dihasilkan, daerah sebenarnya sudah sangat memerlukan kebijakan baru yang secara tegas mengatur cara masyarakat berpartisipasi dalam pembuatan kebijakan. Partisipasi dapat dilaksanakan melalui cara:

\section{Rekomendasi-rekomendasi penelitian} kebijakan dan naskah akademik

Mekanisme ini berbentuk kerjasama dengan pemangku kepentingan dari perguruan tinggi atau pihak lain. Instansi pemrakarsa kebijakan melampirkan rekomendasi dan draft naskah akademik sebagai keharusan bersama rancangan peraturan. Konsekuensi dari rancangan yang diajukan tanpa rekomendasi dan draft naskah akademik maka DPRD tidak berkewajiban membahas rancangan tersebut.

2. Diskusi terbuka seperti seminar, lokakarya dan FGD (diskusi kelompok terfokus)

Mekanisme diterapkan sebelum rancangan disahkan DPRD. Kewajibannya di pihak pemrakarsa melalui informasi dan undangan kepada pemangku kepentingan.

3. Memo kebijakan atau ringkasan kebijakan, dikembangkan dengan para pemangku kepentingan lokal dan disebarkan secara luas

Dihasilkan dari para ahli ataupun pemangku kepentingan berupa hasil analisis atau kajian kebijakan terhadap rancangan peraturan yang disebarluaskan pemrakarsa kebijakan. Penyampaian aspirasi dilakukan sebelum kebijakan disahkan dewan.

4. Penerbitan kebijakan daerah dalam media cetak dan elektronika

Mekanisme ini dilaksanakan pada tahap perancangan maupun setelah suatu kebijakan itu ditetapkan sebagai bagian tugas instansi pemrakarsa.

5. Dengar pendapat (public hearing) di DPRD Dewan mengundang pemangku kepentingan membahas rancangan kebijakan secara bersama pada tahap rapat-rapat pembahasan sebelum kebijakan disahkan. Agenda pembahasan rancangan harus terjadwal oleh Panitia Musyawarah DPRD.

6. Menyebarkan rancangan peraturan kepada berbagai pemangku kepentingan, untuk meminta masukan sebagai bahan perumusan kebijakan akhir.

Tanggung jawab pihak perancang meminta kembali masukan masyarakat setelah rancangan tersebut sudah melalui proses perbaikan atau revisi.

\section{Melegalisasi partisipasi dalam pembuatan kebijakan daerah}

Dibutuhkan kebijakan baru yang secara tegas mengatur bagaimana partisipasi masyarakat terakomodasi di segala tahapan, dari proses perancangan hingga pelaksanaan kebijakan sebagai jaminan hukum bagi berbagai pihak untuk sebanyak mungkin memberikan masukan tentang berbagai isu dan memberikan tanggung jawab pada pemerintah daerah untuk pelaksanaannya.

Kebijakan daerah partisipatif perlu memuat aturan-aturan pokok seperti:

\section{Ketentuan Umum}

Ketentuan umum berisi definisi yang dipakai dalam kebijakan daerah. Definisi yang dipakai harus lebih khusus untuk memperjelas suatu pengertian dan tidak menimbulkan pengertian ganda. Hal-hal yang perlu didefinisikan adalah partisipasi masyarakat, warga/masyarakat, kebijakan daerah dan kebijakan publik.

2. Hak dan Kewajiban

Hak masyarakat perlu diakui secara tegas/ eksplisit sebagai hak yang melekat pada masing-masing individu baik sebagai stakeholder atau shareholder. Hak masyarakat dalam pembuatan kebijakan 
adalah hak diinformasikan, hak memberi masukan, hak komplain, dan hak mengawasi pelaksanaan. Konsekuensi pengakuan hak tersebut, penyelenggara pemerintahan berkewajiban ${ }^{7}$ mendengar, memperhatikan dan menjawab pendapat masyarakat serta menjamin terlaksananya hak-hak masyarakat dalam proses pembuatan kebijakan.

3. Asas dan Tujuan Partisipasi

Asasnya adalah kebebasan berpendapat mengeluarkan pikiran secara lisan dan tulisan secara rasional, efisien, tetap guna dan tepat sasaran. Sedangkan tujuannya yaitu meningkatkan kualitas dan keefektifan kebijakan yang dirumuskan dan ditetapkan dalam membangun pemerintahan yang demokratis dan partisipatif. Tujuan lainnya adalah meningkatkan kesadaran masyarakat akan makna penting peran dan tanggung jawab bersama guna ikut menentukan arah masa depan kehidupannya sesuai dengan nilai-nilai budaya lokal maupun kebijakan nasional.

\section{Pelaksanaan Partisipasi Masyarakat}

a. Bidang-bidang pelibatan masyarakat. Perumusan visi, misi dan rencana strategis; penyusunan program pembangunan daerah; penyusunan APBD; penyusunan/revisi tata ruang; penyusunan peraturan daerah; pengawasan dan evaluasi pelaksanaan kebijakan atau program; dan lain-lain perumusan kebijakan daerah berkaitan dengan kepentingan rakyat banyak.

b. Substansi pelibatan masyarakat. Pelibatan masyarakat minimal harus menjamin terlaksananya hak masyarakat, sehingga mekanisme partisipasi ini setidaknya mengatur halhal sebagai berikut:

- Penyampaian informasi tentang kebijakan yang akan diambil termasuk jadwal dan prosedur pelibatan masyarakat;

- Tanggapan terhadap aspirasi masyarakat;

- Hasil akomodasi aspirasi masyarakat dan keberatan.

c. Jadwal penyampaian dan tanggapan pelibatan masyarakat.

Tenggang waktu informasi dan jadwal pelibatan masyarakat diatur sedemikian rupa sehingga cukup waktu bagi masyarakat untuk mempersiapkan secara baik pikiran dan pendapatnya sebelum proses penetapan kebijakan.

d. Dokumentasi proses partisipasi.

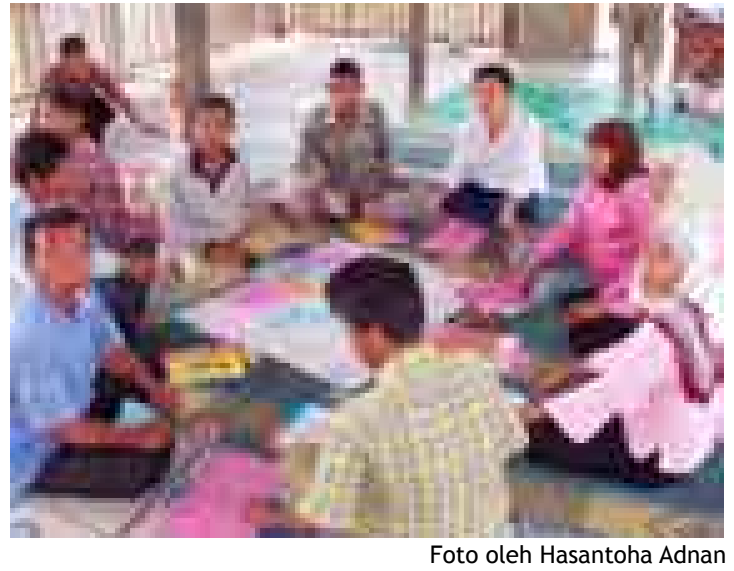

Semua dokumen terkait proses partisipasi seperti konsep, rancangan, hasil hasil akhir kebijakan, publikasi, tanggapan, keberatan masyarakat dan notulensi pembuatan kebijakan harus didokumentasikan dan menjadi dokumen terbuka untuk umum.

\section{Pengaduan}

Jika prosedur pelibatan masyarakat tidak dilaksanakan, penting penyiapan pengaturan pengaduan sebagai upaya untuk menjamin diperhatikannya prosedur pelibatan masyarakat oleh penyelenggara pemerintahan karena masyarakat akan dapat menggugat kebijakan yang dihasilkan tanpa prosedur pelibatan masyarakat.

\section{Sanksi}

Dalam memberikan kekuatan aturan maka perlu dicantumkan sanksi. Tidak dilaksanakannya ketentuan yang diatur dalam kebijakan lebih merupakan pelanggaran bukan kejahatan. Sanksi harus diatur sedemikian rupa agar dapat dicapai efek jera tetapi juga harus dipertimbangkan sanksi yang mungkin diterapkan.

Partisipasi masyarakat perlu dilegalkan dalam bentuk peraturan daerah untuk membuka ruang yang cukup luas bagi masyarakat berpartisipasi, sehingga dapat dikembangkan bentuk dan mekanisme partisipasi yang baik guna membangun konsensus dan sinergi antar pemangku kepentingan dalam penyusunan kebijakan.

Kebijakan daerah partsipatif menjadi modal dasar bagi lahirnya kebijakan nasional yang diharapkan menjadi rujukan bersama seluruh daerah untuk mengimplementasikan lahirnya kebijakan partisipatif yang benar-benar lebih berorientasi pada masyarakat. 


\section{Catatan Akhir}

1 Partisipasimasyarakatdalamperkembangannya meliputi pengertian partisipasi masyarakat sebagai kebijakan, partisipasi masyarakat sebagai strategi, partisipasi masyarakat sebagai alat komunikasi, partisipasi masyarakat sebagai alat penyelesaian sengketa, dan partisipasi masyarakat sebagai terapi.

2 Makna partisipasi seringkali dilihat sematamata sebagai penyampaian informasi, penyuluhan, mengundang dengar pendapat, mengadakan seminar dan rapat atas sesuatu hal atau bahkan sekedar alat public relation agar proyek dapat berjalan tanpa hambatan. Namun syarat utama yang melandasi partisipasi malah diabaikan, yaitu informasi yang lengkap dan terus-menerus dari masalah yang dibicarakan.

3 Lihat ketentuan Pasal 68 UU Kehutanan No. 41/1999, Pasal 4 (5) UU No. 34/2000 tentang Pajak dan Retribusi Daerah, Pasal 53 UU No. 10/2004 tentang Pembentukan Peraturan Perundang-undangan, dan lihat konsideran menimbang huruf a UU No. 32/2004 tentang Pemerintahan Daerah.

4 Lihat peraturan daerah mengenai Propeda di Provinsi Jambi bab VII (Perda No. 14A/2001).

5 Proses pembuatan kebijakan melalui empat tahap yaitu perancangan oleh instansi pemrakarsa, penyelarasan rancangan di bagian hukum Setda, tahap pra persidangan, dan tahap persidangan dewan meliputi paripurna I (penyampaian nota pengantar raperda dari kepala daerah), paripurna II (pandangan umum fraksi), paripurna III (tanggapan eksekutif), paripurna IV (penyampaiai hasil pansus) dan paripurna $\checkmark$ (pandangan akhir fraksi dan pengesahan dilanjutkan sambutan kepala daerah).

6 Kelemahannya meliputi kelemahan proses, kelemahan substansi, dan kelemahan legal drafting.

7 Kewajiban secara seimbang untuk taat pada kebijakan partisipatif yang dilahirkan mengikat pihak pemerintah dan masyarakat.

\section{Publikasi terkait}

Gunawan, H. 2005. Desentralisasi: ancaman dan harapan bagi masyarakat adat - studi kasus masyarakat adat Cerekang di Kabupaten Luwu Timur, propinsi Sulawesi Selatan. Bogor, Indonesia, CIFOR. Forests and Governance Programme Series. v, 24p.

Lestiawati, Y. 2005. Kehutanan daerah di era desentralisasi penghambat koordinasi?. CIFOR Governance Brief No. 5. $4 \mathrm{p}$.

Sumarlan. 2005. Kupu-kupu sayap burung musnah, masyarakat pegunungan Arfak menderita. CIFOR Governance Brief No. 6. 2p.

Sukardi. 2005. Mencari benang merah kelangsungan hutan adat ongkoe di Kabupaten Barru. CIFOR Governance Brief No. 7. 2p.

Gunawan, H. 2005. Implementasi desentralisasi salah masyarakat adat menuai masalah. CIFOR Governance Brief No. 8. 4p.

Yulianti, A. 2005. Kopermas: masyarakat hukum adat sebagai tameng bagi pihak yang berkepentingan. Bogor, Indonesia, CIFOR. CIFOR Governance Brief No. 9. $4 \mathrm{p}$.

Yusran. 2005. Mengembalikan kejayaan hutan kemiri rakyat. Bogor, Indonesia, CIFOR. CIFOR Governance Brief No. 10. $4 p$.

Angi, E.M. 2005. Bagaimanakebijakandapatdikoordinasikan antara pusat, daerah dan masyarakat?. Bogor, Indonesia, CIFOR. CIFOR Governance Brief No. 11. $4 p$.

Affandi, O. 2005. Dampak Kebijakan IPPK dan IUPHHK Terhadap Perekonomian Masyarakat di Kabupaten Malinau. Bogor, Indonesia, CIFOR. CIFOR Governance Brief No. 12. 6p

Wiati, C.B. 2005. Apakah Setelah Desentralisasi Hutan Penelitian Lebih Bermanfaat Untuk Masyarakat Lokal?. Bogor, Indonesia, CIFOR. CIFOR Governance Brief No. 13. 4p.

Agusnawati 2006. Peran kaum perempuan dalam pengambilan keputusan pada masyarakat pengelola hutan kemiri di Mario Pulana. CIFOR Governance Brief No.28. 4p.

Muntasyarah, A.S. 2006. Agroforest karet di Jambi: dapatkah bertahan di era desentralisasi? CIFOR Governance Brief No.31. 4p.

Governance brief ini ditulis dalam rangka partisipasi penulis dalam program “Building Leadership for Forest Reforms of the Future" yang diselenggarakan atas kerjasama CIFOR dan Ford Foundation Jakarta. Tulisan ini merupakan ringkasan Governance Paper dengan judul "Naskah Akademik Perda tentang Mekanisme Partisipasi Masyarakat Dalam Pembuatan Kebijakan", 2005
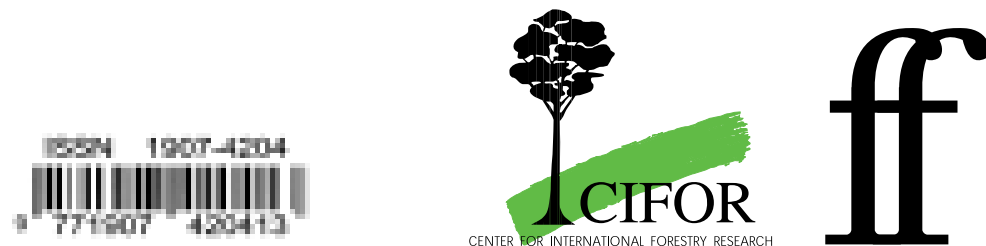

Center for International Forestry Research, CIFOR Alamat kantor: Jalan CIFOR, Situ Gede, Sindang Barang Bogor Barat 16680, Indonesia.

Alamat surat: P.O. Box. 6596 JKPWB, Jakarta 10065 Indonesia
Tel: +62(251) 622622 Fax: +62(251) 622100

E-mail: cifor@cgiar.org

Website: www.cifor.cgiar.org

Foto sampul oleh Christian Cossalter dan Sudirman

Program Forests and Governance di CIFOR mengkaji cara pengambilan dan pelaksanaan keputusan berkenaan dengan hutan dan masyarakat yang hidupnya bergantung dari hutan. Tujuannya adalah meningkatkan peran serta dan pemberdayaan kelompok masyarakat yang kurang berdaya, meningkatkan tanggung jawab dan transparansi pembuat keputusan dan kelompok yang lebih berdaya dan mendukung proses-proses yang demokratis dan inklusif yang meningkatkan keterwakilan dan pengambilan keputusan yang adil di antara semua pihak. 